\title{
Wood and Briquette Density Under the Effect of Fertilizers and Water Regimes
}

\author{
Raissa Tavares Silva ${ }^{1}$ (D), Carlos Roberto Sette Junior ${ }^{1}$ (D), Angel Ferreira ${ }^{2}$ (D), \\ Matheus Peres Chagas $^{1}$ (D), Mario Tomazello Filho ${ }^{2}$ \\ ${ }^{1}$ Setor de Engenharia Florestal, Escola de Agronomia, Universidade Federal de Goiás - UFG, Goiânia/GO, Brasil \\ ${ }^{2}$ Departamento de Ciências Florestais - LCF, Escola Superior de Agricultura "Luiz de Queiroz" - ESALQ, Universidade de \\ São Paulo - USP, Piracicaba/SP, Brasil
}

\begin{abstract}
The aim of this study was to evaluate the effects of potassium and sodium fertilization (control: 4.5kmol.ha ${ }^{-1}$ of $\mathrm{KCl}$ and $4.5 \mathrm{kmol} . \mathrm{ha}-1$ of $\left.\mathrm{NaCl}\right)$, and water regimes $(100 \%$ and $63 \%$ rainfall with artificial exclusion) on wood and briquette density in Eucalyptus grandis trees at 5 years, and the application of X-ray densitometry on the quality of briquettes. Tree trunk samples were obtained to determine wood density, production and briquette density by X-ray densitometry and stereometric. The artificial exclusion of rainwater promoted an increase in wood density, and the fertilization treatments versus water availability did not affect the density of briquettes. The method used to determine the briquette density influenced the average values, with an increase of $12 \%$ in the X-ray densitometry to the stereometric.
\end{abstract}

Keywords: Eucalyptus, densified materials, quality. 


\section{INTRODUCTION}

The use of forest biomass stands out for its representativeness in the Brazilian forestry sector and for its growth perspective for being among the most sustainable in the world, totaling an area of 7.8 million hectares of planted trees, with 5.6 million hectares of species of the Eucalyptus genus (Indústria Brasileira de Árvores - IBÁ, 2015). The use of densified materials such as briquettes can be highlighted among the possibilities of using this raw material for generating energy.

Densified materials are direct substitutes for firewood in various applications, including for residential use, and in industries and commercial establishments such as brick yards, ceramic manufacturers, pizzerias, bakeries, dairy farms, food factories, chemical industries, textile industries, and cement industries, among others (Dias et al., 2012). Briquettes have higher characteristics compared to other biomass products such as firewood, mainly in relation to the mass and energy density (Arranz et al., 2015). In Brazil, about 1.2 million tons of briquettes are produced per year, of which 930 thousand tons are made of wood (ABIB, 2012).

On the other hand, a large part of eucalyptus plantations is inserted in less fertile areas, mainly lacking potassium $(\mathrm{K})$ and subjected to periods of water deficit (Gonçalves et al., 2013). Scientific studies have pointed out the effects of fertilizer application and water availability on growth, productivity and wood quality of different species of Eucalyptus (Subbarao et al., 2000; Benlloch-González et al., 2008; Sette et al., 2009 and 2010). The changes in wood quality of trees indicated in the literature due to fertilization and water availability can influence the energy and physico-mechanical characteristics of the biomass and derived products such as briquettes.

The literature presents a great number of scientific studies indicating the effects of fertilizers application on the quality of $E$. grandis wood, indicating an increase (Sette et al., 2014) or reduction (Washusen et al., 2005) in the density.

Several studies have demonstrated the significant effects of water availability on wood density in forest species, such as Bouriaud et al. (2005) and Drew et al. (2009) that found a significant increase in the wood density of Eucalyptus species in response to a decrease in water availability. Wood density in trees is related to the edaphoclimatic and physiographic characteristics of the site; in areas of higher rainfall, there is a tendency for a greater exchange rate in the trees, with increased growth and formation of thin-walled fibers and larger diameter vessels, thus resulting in wood of lower density. Similarly, in lower rainfall areas or periods of the year, the trunk presents slower growth and forms wood with thicker wall fiber, as well as smaller diameter and vessels of greater density.

Although some studies have already pointed out the effect of fertilization on plants' acclimatization to drought, field studies on trees older than four years, which focus on the interaction of $\mathrm{K}$ and $\mathrm{Na}$ fertilization and the partial exclusion of rainfall, are scarce in tropical areas. Considering that biomass production for bioenergy and its quality can be influenced by fertilization and water availability, it is essential to understand the interaction of these factors and their influence on the quality of briquettes produced with eucalyptus wood.

Sodium $(\mathrm{Na})$ and potassium $(\mathrm{K})$ are monovalent, structurally and chemically similar cations (Subbarao et al., 2003) that share some physiological functions (Battie-Laclau et al., 2014a, b). Thus, Na assumes similar functions to $\mathrm{K}$ in plant metabolism (Almeida et al., 2010). Studies as those by Gattward et al. (2012), Sette et al. (2013), Battie-Laclau et al. (2014a) and Freitas et al. (2015) found satisfactory results for trees that received $\mathrm{Na}$, reporting the possibility of partially replacing potassium by sodium.

In this sense, the objective of this study was to evaluate the effects of $\mathrm{K}$ and $\mathrm{Na}$ fertilization and water availability on the density of eucalyptus wood and briquettes, and of applying X-ray densitometry to evaluate the quality of the briquettes.

\section{MATERIAL AND METHODS}

\subsection{Study site and experimental design}

The experiment was located at the Experimental Station of Forest Sciences of Itatinga/SP, located at $23^{\circ} 02^{\prime} \mathrm{S}$ and $48^{\circ} 38^{\prime} \mathrm{W}$, at $857 \mathrm{~m}$ of altitude. The climate of the region is characterized as humid subtropical (Cwa) according to the Köppen classification, with annual average rainfall of $1360 \mathrm{~mm}$, average annual temperature of $19^{\circ} \mathrm{C}$, and average monthly temperatures 
ranging from $15{ }^{\circ} \mathrm{C}$ to $25^{\circ} \mathrm{C}$ in the colder and hotter months, respectively. The soil is Dystrophic Yellow Red Latosol with medium texture.

The experiment was divided into six treatments and three blocks, presenting a total of eighteen plots in split-plot. E. grandis seedlings were planted according to a $3 \times 2 \mathrm{~m}$ spacing, the plots were composed of 12 lines with 12 trees per line (144 trees). Three outer lines correspond to the border within each plot, resulting in an experimental unit of 36 central trees.

The treatments were defined by two water regimes (100\% and $63 \%$ of rainfall, with artificial exclusion using $1700 \mathrm{~m}^{2}$ of polyethylene tarpaulins; the area covered by the tarpaulins represented $37 \%$ of the total area of the experiment) (Figure 1), and three doses of fertilizers

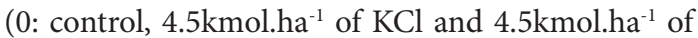
$\mathrm{NaCl})$. The treatments were identified as follows: $\mathrm{C} /+\mathrm{A}$ : control $+100 \%$ of rainfall; $\mathbf{N a} /+\mathrm{A}$ : sodium + $100 \%$ of rainfall; $\mathbf{K} /+\mathbf{A}$ : potassium $+100 \%$ of rainfall; $\mathrm{C} /-\mathrm{A}$ : control $+63 \%$ of rainfall; $\mathrm{Na} /-\mathrm{A}$ : sodium $+63 \%$ of rainfall; and $\mathrm{K} / \mathrm{A}$ : potassium $+63 \%$ of rainfall.

\subsection{Preparation of the samples, wood density determination and production of briquettes}

Nine (9) 5-year-old trees were selected from each fertilization versus water availability treatment, and $5 \mathrm{~cm}$ thick wooden discs and $30 \mathrm{~cm}$ long logs were removed at the $\mathrm{DBH}(1.30 \mathrm{~m})$ from each of them. The wooden discs were conditioned in an air-conditioning chamber until reaching $12 \%$ humidity and were used to determine the wood density by X-ray densitometry as proposed by Sette et al. (2010).

The logs were cut into smaller portions, ground and milled using a Willey-mill to obtain sawdust. The sawdust was dried at $105^{\circ} \mathrm{C}\left( \pm 2^{\circ} \mathrm{C}\right)$ until reaching a constant weight, and then adjusted to $12 \%$ moisture content with the aid of a sprinkler and a semi-analytical balance as proposed by Silva et al (2015). According to Quirino et al. (2012), this moisture content is within the range considered ideal for manufacturing briquettes.

The briquettes were prepared in a laboratory briquetting machine at a temperature of $120{ }^{\circ} \mathrm{C}$ (+ or $-5^{\circ} \mathrm{C}$ ), pressure of $140 \mathrm{kgf} . \mathrm{cm}^{-2}$, compaction time of 5 minutes and cooling for 10 minutes under forced ventilation. The biomass compaction conditions were defined experimentally through preliminary tests for pressing and cooling times.

$40 \mathrm{~g}$ of sawdust were used for each briquette, at the end obtaining a briquette of approximate $4 \mathrm{~cm}$ in length and $3 \mathrm{~cm}$ in diameter. Ten briquettes were produced per treatment, totaling 60 briquettes.

\subsection{Density of the briquettes: stereometric and $X$-ray densitometry}

The briquettes produced for each treatment were conditioned in an air-conditioned room until reaching $12 \%$ moisture content. The density was determined by the stereometric method, which consists in obtaining the volume of each briquette according to measurements
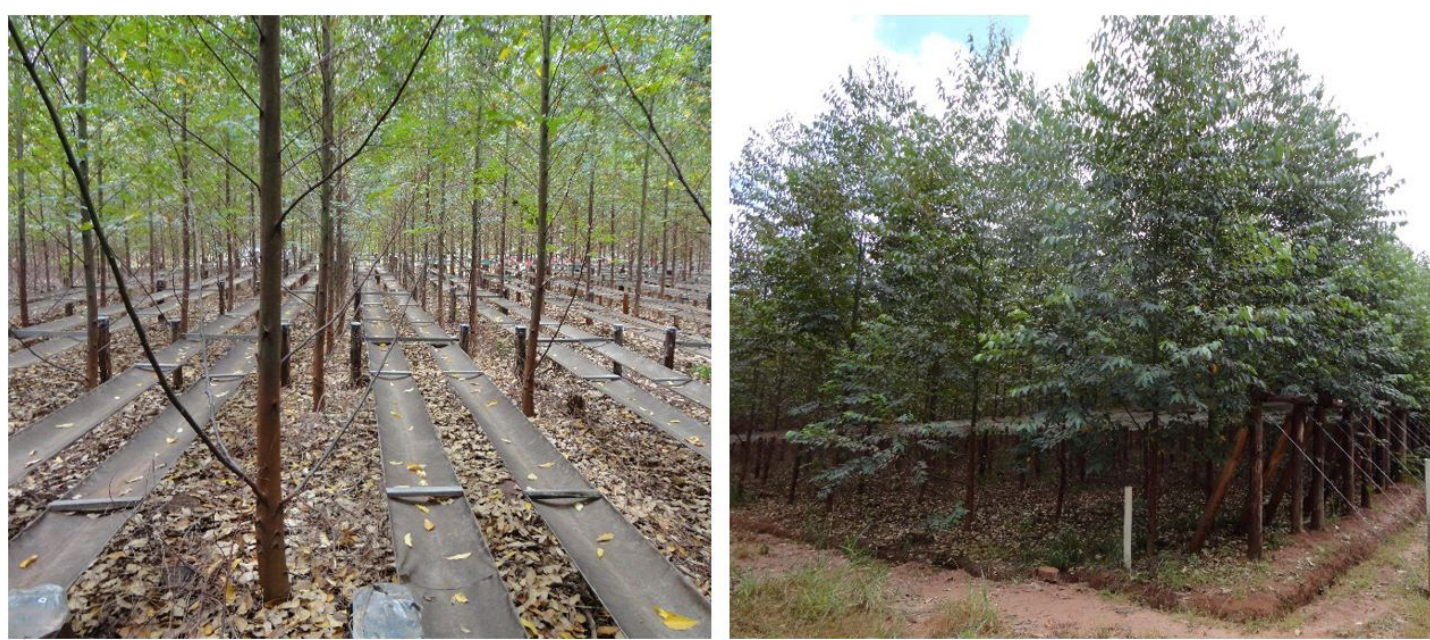

Figure 1. Experimental design with E. grandis trees. Detail for the rainfall reduction using polyethylene strips. 
(diameter and height) using a pachymeter, and the briquette mass using a precision scale of 0.001 grams.

A $3 \mathrm{~mm}$ thick samples was subsequently extracted from the lower portion of each briquette (side facing the bottom of the briquetting machine's cylinder) (Figure 2), as suggested by Quirino et al. (2012). The region for samples removal was determined by a previous digital X-ray image evaluation, indicating a side which is completely free of internal cracks, making it possible to obtain the whole samples required for analysis by X-ray densitometry. The samples were also stored in an air-conditioned room, following the same standards used for the whole briquettes.

The samples were analyzed in QTRS-01X equipment to obtain the densitometric spectrum with the density profile. According to a procedure adapted from Quirino et al. (2012), the samples were fixed to the equipment's metal support in the continuous scanning. For the qualitative analysis, digital radiographic images of whole briquettes and samples were obtained using a LX-60 Faxitron digital X-ray machine, followed by calibration and automatic reading in the range of $30 \mathrm{Kv}$ for a maximum time of 19 seconds.

\subsection{Statistical analysis}

The statistical analysis of the results was based on the experimental design with 6 treatments and 10 replicates. Outliers were determined according to the Box-Plot method, normality of data distribution was determined by the Shapiro-Wilk method, and variance heterogeneity by the Bartlett and Levene methods. The data presented normality of distribution and homogeneity of variance; the analysis of variance
(ANOVA) was applied to determine the treatment effects on the wood and briquette density, and the determination method.

\section{RESULTS AND DISCUSSION}

The wood and the briquette densities values from the 5-year-old eucalyptus trees under the fertilization treatments versus water availability are presented in Table 1 . The average wood density with a $37 \%$ reduction in the levels (63\% water availability) was $0.54 \mathrm{~g} . \mathrm{cm}^{-3}$, which was statistically higher than the wood density of the trees submitted to $100 \%$ water availability with an average of $0.48 \mathrm{~g} . \mathrm{cm}^{-3}$.

Scientific studies reported in the literature verify the increase of the wood density in Eucalyptus species in regions subjected to water stress (Drew et al., 2009). Trees affected by water stress reduce their growth rate by changing their exchange rate, in addition to reducing

Table 1. Wood and briquette density per treatment.

\begin{tabular}{|c|c|c|}
\hline \multirow{2}{*}{ Treatments } & Wood density & Briquette density \\
\hline & $\left(\mathrm{g} \cdot \mathrm{cm}^{-3}\right)$ & $\left(\mathrm{g} \cdot \mathrm{cm}^{-3}\right)$ \\
\hline $\mathrm{C} /+\mathrm{A}$ & $0.49 \mathbf{a}(0.02)$ & $1.21 \mathbf{a}(0.07)$ \\
\hline $\mathrm{Na} /+\mathrm{A}$ & $0.47 \mathbf{a}(0.01)$ & $1.22 \mathbf{a}(0.08)$ \\
\hline $\mathrm{K} /+\mathrm{A}$ & $0.48 \mathbf{a}(0.02)$ & $1.15 \mathrm{a}(0.10)$ \\
\hline Mean & 0.48 A (0.01) & 1.19 A (0.07) \\
\hline C/-A & $0.55 \mathbf{b}(0.01)$ & $1.18 \mathbf{a}(0.07)$ \\
\hline $\mathrm{Na} /-\mathrm{A}$ & $0.53 \mathbf{b}(0.02)$ & 1.17 a $(0.08)$ \\
\hline $\mathrm{K} /-\mathrm{A}$ & $0.53 \mathbf{b}(0.01)$ & $1.18 \mathbf{a}(0.07)$ \\
\hline Mean & 0.54 B $(0.02)$ & $1.18 \mathrm{~A}(0.06)$ \\
\hline
\end{tabular}

Mean followed by standard deviation. Mean followed by the same letter did not differ from one another at $95 \%$ probability by the Tukey test. Lowercase letters: comparison between treatments; and uppercase letters: comparison between $+\mathrm{A}$ and $-\mathrm{A}$.

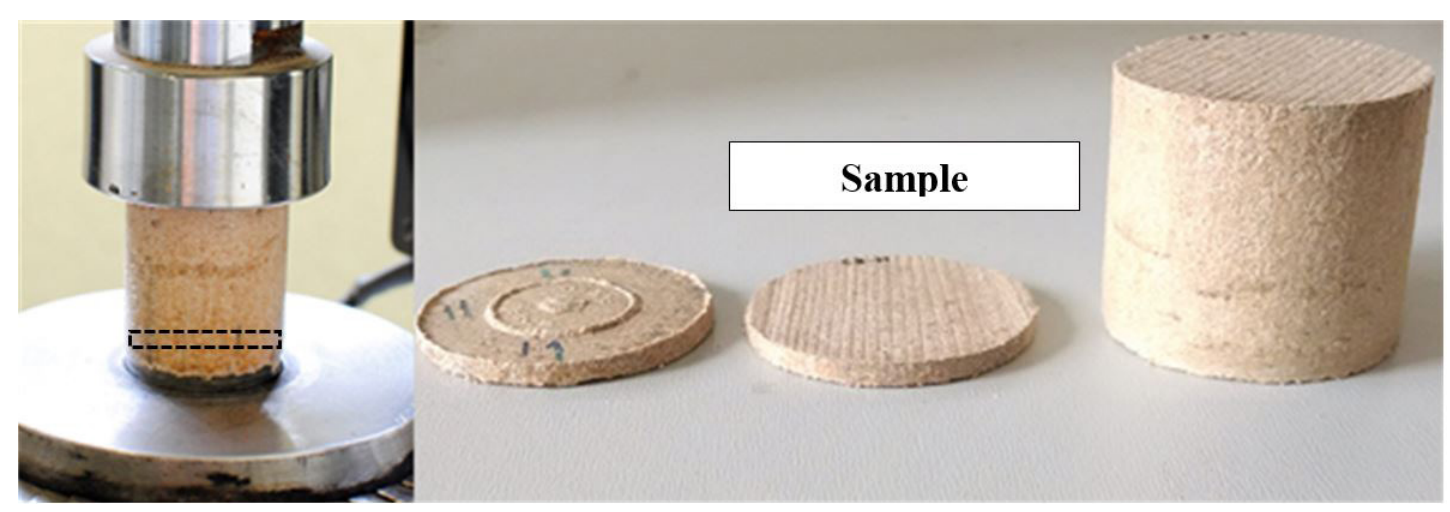

Figure 2. Briquette and region from where the samples for X-ray densitometry were obtained. 
leaf area, increasing the biomass of the roots and altering the structure of the xylem in order to avoid cavitation (Carter \& White, 2009). There is cell wall thickening mainly as a consequence of the reduced growth rate due to carbohydrate deposition, thus increasing the density (Panshin \& Zeeuw, 1970).

No significant differences were observed in the mean values for the wood basic density in evaluating the isolated effect of applying $\mathrm{K}$ and $\mathrm{Na}$ for each water availability (+A and -A). In Eucalyptus trees of advanced ages (up to 30 years), the results of studies concerning the effect of mineral fertilizers on the wood properties are controversial, indicating increases and reductions in the wood density (Washusen et al., 2005). The results of Sette et al. (2014) when studying young eucalyptus trees (1-4 years) may be highlighted because they did not find a significant effect of mineral fertilization on the wood density.

Briquette density produced with the wood from the experimental eucalyptus trees was not influenced by the fertilization treatments versus water availability, with mean values ranging from 1.15 to $1.22 \mathrm{~g} . \mathrm{cm}^{-3}$. The results of studies on the effect of mineral fertilizers and water availability on the density of densified materials such as briquettes and pellets are non-existent, restricting discussion of the data found in this study. However, the differences in the behavior of bulk density between wood and briquettes depending on the applied treatments is related to the briquetting conditions (pressure and temperature), which tend to have a more significant influence on the physical properties of densified materials (Carone et al., 2011), thus making the mean values more homogeneous, regardless the applied fertilization and the reduced rainfall levels.

Density indicates the physical quality of densified solid biofuels (Temmerman et al., 2006), reflecting the amount of accumulated energy (Quirino et al., 2004) and its variation to the biomass characteristics such as granulometry, moisture and lignin contents, and the compaction process such as the applied pressure (dimension and time) and temperature (Dick et al., 2007; Mahapatra et al., 2010), which can be controlled to enhance the production efficiency and improve the quality of the final product (Carone et al., 2011).

Mean density values for all fertilization treatments versus water availability are in agreement with those presented in the literature for eucalyptus briquettes (Protásio et al., 2011; Gonçalves et al., 2013) and higher than the wood bulk density. This increase in density after compaction demonstrates the importance of biomass densification processes for the best use of lignocellulosic materials for producing bioenergy, since the increase in the briquette density represents a decrease in the biomass volume, leading to greater mass concentration in the same space (Silva et al., 2015).

The briquette density values by $\mathrm{X}$-ray densitometry and the stereometric method for each treatment of fertilization versus water availability are presented in Table 2. Significant effects were observed on the mean density of $E$. grandis briquettes by X-ray densitometry under the isolated effect of nutrition in a natural water regime in the control treatment ( $100 \%$ of rainfall): for the $\mathrm{K} /+\mathrm{A}$ treatment, with higher values than for the $\mathrm{C} /+\mathrm{A}$ treatment.

The method used for determining the briquette density had a significant influence ( $\alpha=0.05)$ on the mean values, reaching $1.04 \mathrm{~g} . \mathrm{cm}^{-3}$ for $\mathrm{X}$-ray densitometry and $1.18 \mathrm{~g} . \mathrm{cm}^{-3}$ for the stereometric method, with increases of $12 \%$ (Table 2), as also observed by Quirino et al. (2012). This difference observed between the methods may be associated with the variation amplitude of the density due to the heterogeneity in the briquette's granulometric composition (Figure 3), as detected by the accuracy of the X-ray densitometry method, with readings at intervals of $80 \mu \mathrm{m}$.

$\mathrm{X}$-ray densitometry has been applied for determining density and its variation in the $\mathrm{X}$-rays by numerous authors (Sette et al., 2016) to analyze the wood from different species of eucalyptus trees at different ages and locations; however, without being used in densified

Table 2. Mean bulk density of Eucalyptus briquettes determined by X-ray and stereometric methods.

\begin{tabular}{ccc}
\multirow{2}{*}{ Treatment } & \multicolumn{2}{c}{ Mean bulk density $\left(\mathbf{g} \cdot \mathbf{c m}^{-3}\right)$} \\
\cline { 2 - 3 } $\mathrm{C} /+\mathrm{A}$ & X-ray & Stereometric \\
$\mathrm{Na} /+\mathrm{A}$ & $1.01 \mathrm{aA}(0.02)$ & $1.21 \mathrm{aB}(0.07)$ \\
$\mathrm{K} /+\mathrm{A}$ & $1.07 \mathrm{bA}(0.01)$ & $1.22 \mathrm{aB}(0.08)$ \\
$\mathrm{C} /-\mathrm{A}$ & $1.06 \mathrm{abA}(0.02)$ & $1.15 \mathrm{aB}(0.10)$ \\
$\mathrm{Na} /-\mathrm{A}$ & $1.05 \mathrm{abA}(0.03)$ & $1.18 \mathrm{aB}(0.07)$ \\
$\mathrm{K} /-\mathrm{A}$ & $1.05 \mathrm{abA}(0.03)$ & $1.18 \mathrm{aB}(0.08)$ \\
\hline $\mathrm{Mean}$ & $1.04 \mathrm{~A}(0.02)$ & $1.18 \mathrm{~B}(0.06)$ \\
\hline
\end{tabular}

Mean followed by standard deviation. Mean followed by the same letter did not differ from one another at $95 \%$ probability, by the Tukey test. Lowercase letters: comparison between treatments; and uppercase letters: comparison between methods. 
materials. When applied in the quality analysis of briquettes, it can help to define how briquetting factors (temperature, pressure, pressing time, and granulometry) will be administered in producing briquettes for which improved characteristics are sought (Quirino et al., 2012).

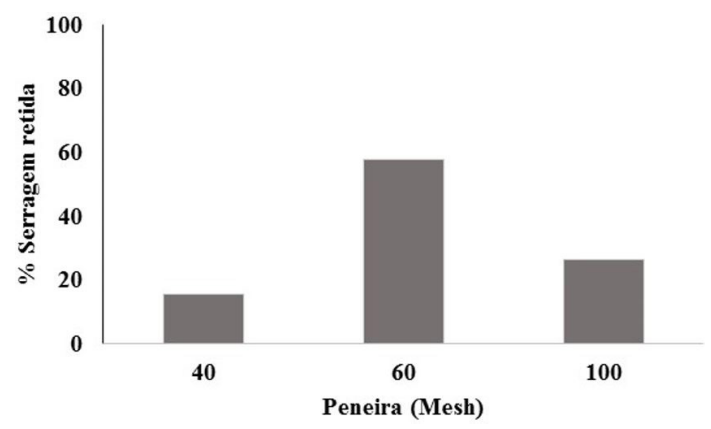

Figure 3. Grain size classification of E. grandis sawdust used in manufacturing the briquettes. Average of all fertility versus water availability treatments.
The X-ray densitometry profiles of the briquettes show a non-homogeneous distribution for a common variation model for all applied fertilization treatments versus water availability (Figure 4), characterized by values ranging from $0.94-1.03 \mathrm{~g} . \mathrm{cm}^{-3}$ in the peripheral regions, and of $0.99-1.13$ g.cm ${ }^{-3}$ in the central region, with some density fluctuations mainly due to variations in particle size, as already discussed and presented in Figure 3. Furthermore, the difficulty in obtaining samples with perfectly flat and homogeneous surfaces (Quirino et al., 2012) influences the result due to the sensitivity of the measurement methodology.

A qualitative evaluation of the briquettes' internal structure performed on the digital X-ray equipment evidences cracks present for all fertilization treatments versus water availability (Figure 5). The presence of cracks is already recognized in other biomass compaction processes such as pelleting and is attributed to inadequate moisture level or inadequate
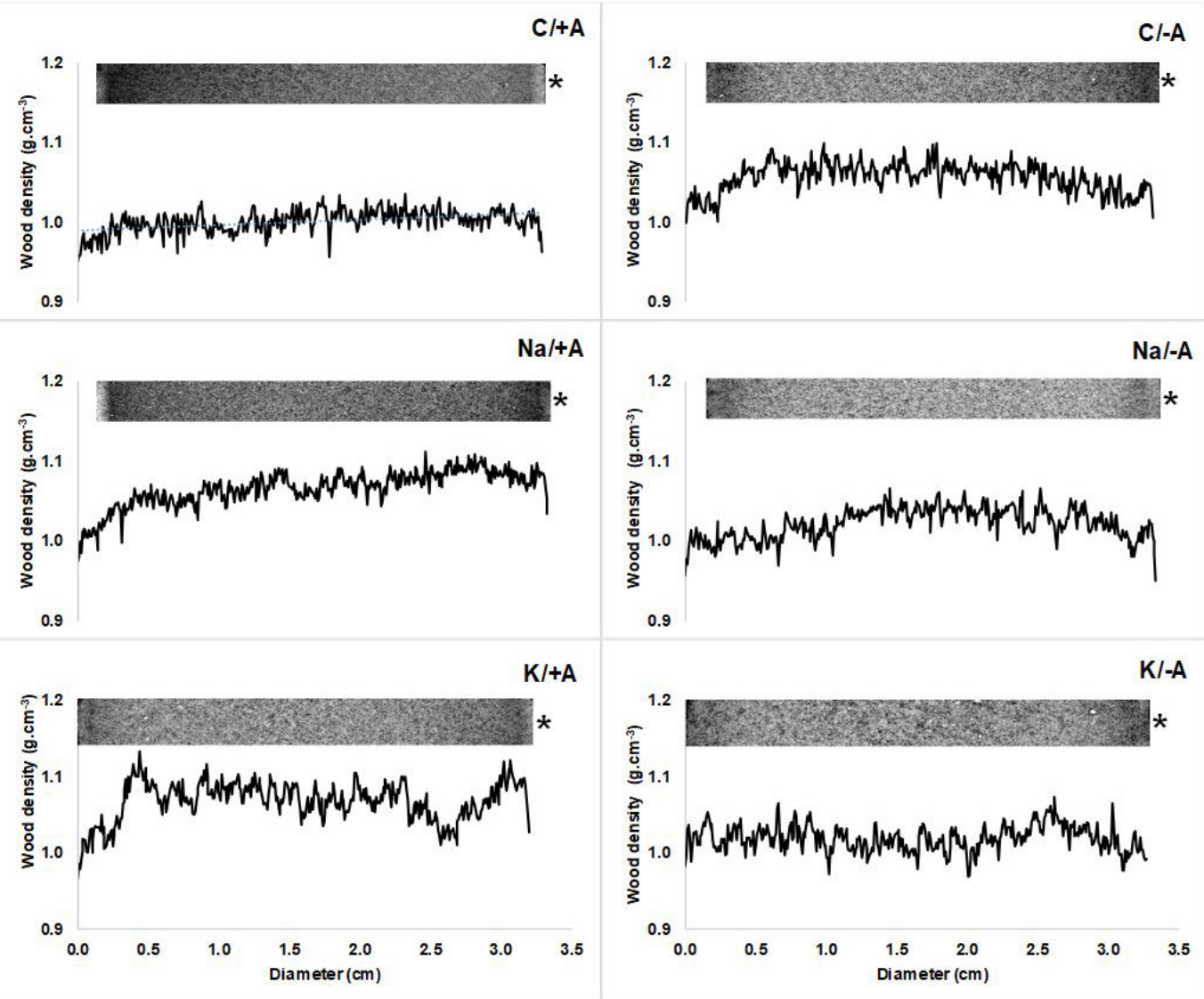

Figure 4. Diametric variation of the mean density of eucalyptus briquettes for all fertilization treatments versus water availability. ${ }^{*}$ diametric section of the briquette obtained by digital X-ray. 


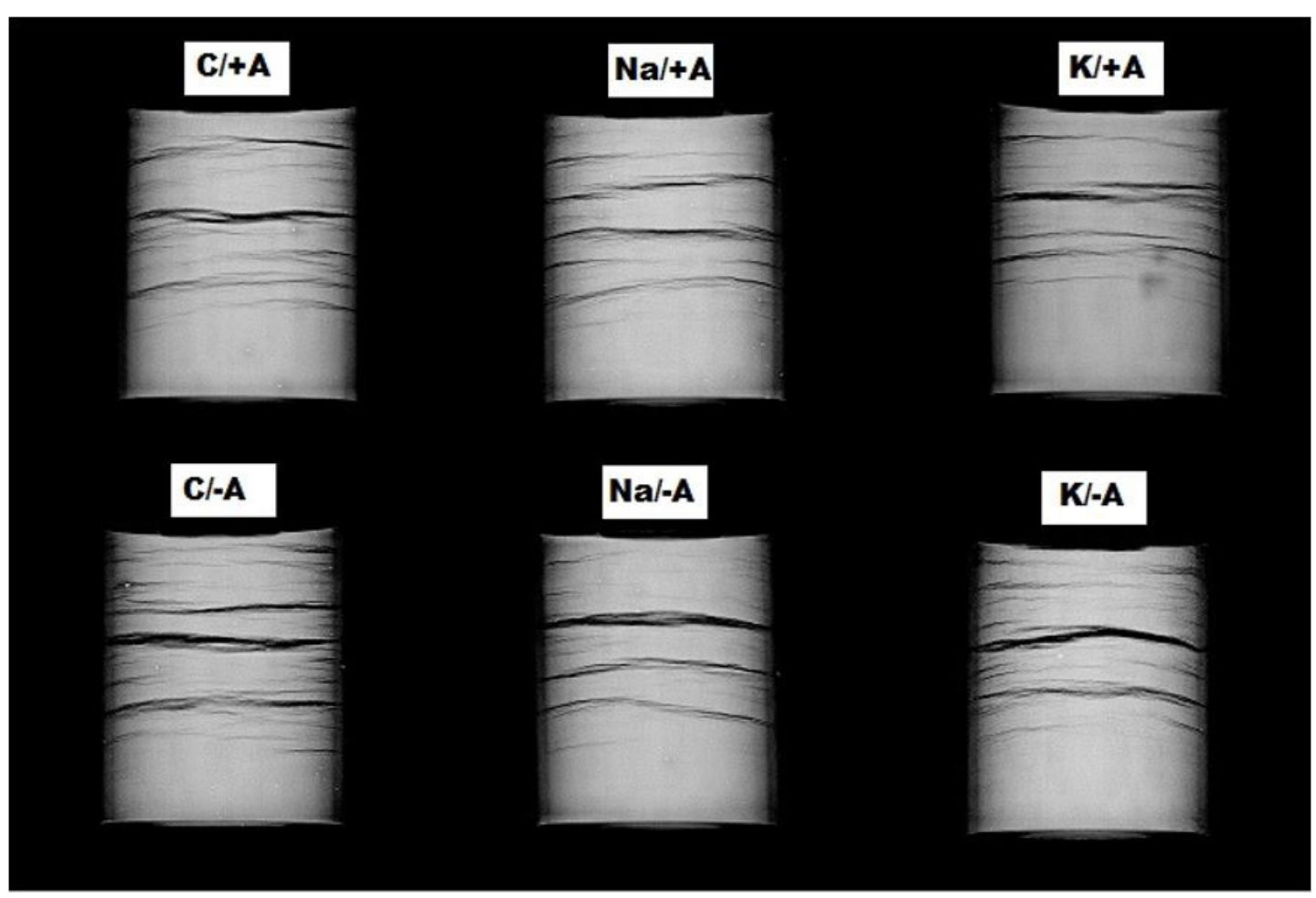

Figure 5. Digital X-ray images of eucalyptus briquettes for fertilizer treatment versus water availability.

particle size (Arágon-Garita et al., 2016), or to the temperature variation and internal pressure in the briquette during compaction (Quirino et al., 2012). Cracks may negatively interfere in the briquette quality, influencing their physical properties which can affect strength and durability.

An evaluation of other physico-mechanical properties of the briquettes produced with biomass from eucalyptus trees submitted to different growth conditions (fertilization and water availability) is recommended.

\section{CONCLUSIONS}

The 37\% reduction in precipitation levels promoted an increase in the mean wood density of E. grandis, while applying fertilizers with potassium and sodium had no effect on the wood density.

The mean of briquettes density produced with E. grandis wood did not undergo an effect from fertilization treatments versus water availability.

The method used to determine the briquette density significantly influenced the mean values, with increases of $12 \%$ for the X-ray densitometry compared to the stereometric method, with internal cracks observed in the briquettes.

\section{SUBMISSION STATUS}

Received: 13 sep., 2016

Accepted: 24 jan., 2018

\section{CORRESPONDENCE TO}

\section{Carlos Roberto Sette Junior}

Setor de Engenharia Florestal, Escola de Agronomia, Campus Samambaia, Universidade Federal de Goiás - UFG, Rodovia Goiânia/Nova Veneza, Km 0, CP 131, CEP 74690-900, Goiania, $\mathrm{GO}$, Brasil

e-mail: crsettejr@hotmail.com

\section{FINANCIAL SUPPORT}

Centre de Coopération Internationale en Recherche Agronomique pour le Développement da França (CIRAD). Conselho Nacional de Desenvolvimento Científico e Tecnológico. 


\section{REFERENCES}

Almeida J, Laclau JP, Gonçalves JLM, Ranger J, SaintAndré L. A positive growth response to $\mathrm{NaCl}$ applications in Eucalyptus plantations established on K-eficient soils. Forest Ecology and Management 2010; 259(1): 1786-1795. http://dx.doi.org/10.1016/j.foreco.2009.08.032.

Arágon-Garita S, Moya R, Bond B, Valaert J, Tomazello M Fo. Production and quality analysis of pellets manufactured from five potential energy crops in the Northern Region of Costa Rica. Biomass and Bioenergy 2016; 87(1): 84-95. http://dx.doi.org/10.1016/j.biombioe.2016.02.006.

Arranz JI, Miranda MT, Montero I, Sepúlveda FJ, Rojas CV. Characterization and combustion behaviour of comercial and experimental wood pellets in South West Europe. Fuel 2015; 142: 199-207. http://dx.doi.org/10.1016/j. fuel.2014.10.059.

Battie-Laclau P, Laclau JP, Domec JC, Christina M, Bouillet JP, Piccolo MC et al. Effects of potassium and sodium supply on drought-adaptive mechanisms in Eucalyptus grandis plantations. The New Phytologist 2014a; 203(2): 401-413. http://dx.doi.org/10.1111/nph.12810. PMid:24725318.

Battie-Laclau P, Laclau JP, Beri C, Mietton L, Muniz MR, Arenque $\mathrm{BC}$ et al. Photosynthetic and anatomical responses of Eucalyptus grandis leaves to potassium and sodium supply in a field experiment. Plant, Cell \& Environment 2014b; 37(1): 70-81. http://dx.doi.org/10.1111/pce.12131. PMid:23663049.

Benlloch-González M, Arquero O, Fournier JM, Barranco D, Benlloch M. K+ starvation inhibits water-stress-induced stomatal closure. Journal of Plant Physiology 2008; 165(6): 623-630. http://dx.doi.org/10.1016/j.jplph.2007.05.010. PMid:17723253.

Bouriaud O, Leban JM, Bert D, Deleuze C. Intra-annual variations in climate influence growth and wood density of Norway spruce. Tree Physiology 2005; 25(6): 651-660. http:// dx.doi.org/10.1093/treephys/25.6.651. PMid:15805085.

Brazilian Association Industry Biomass and Renewable Energy - ABIB. Brazil status report 2012: bioenergy, biomass, renewable energy [online]. 2012 [cited 2016 may 28]. Available from: http://abibbrasil.wix.com/ brazilianassociationbiomass

Carone MT, Pantaleo A, Pellerano A. Influence of process parameters and biomass characteristics on the durability of pellets from the pruning residues of Olea europaea L. Biomass and Bioenergy 2011; 35(1): 402-410. http://dx.doi. org/10.1016/j.biombioe.2010.08.052.

Carter JL, White DA. Plasticity in the Huber value contributes to homeostasis in leaf water relations of a mallee Eucalypt with variation to groundwater depth. Tree Physiology 2009; 29(11): 1407-1418. http://dx.doi. org/10.1093/treephys/tpp076. PMid:19797243.
Dias JMCS, Souza DT, Onoyama MM, Miranda CHB, Barbosa PFD, Rocha JD. Produção de briquetes e péletes a partir de resíduos agrícolas, agroindustriais e florestais. 1st ed. Brasília: Embrapa Agroenergia; 2012.

Dick EP, Ryabov GA, Tugov AN, Soboleva AN. Comparing properties of coal ash and alternativefuel ash. Therm Energy 2007; 54(1): 231-235. http://dx.doi.org/10.1134/ S004060150703010X.

Drew DM, Geoffre YM, Downes GM, Grady AP, Read J, Worledge D. High resolution temporal variation in wood properties. In: Irrigated and non-irrigated Eucalyptus globulus. Annals of Forest Science 2009; 66(1): 1-10.

Freitas PC, Sette CR Jr, Castro VR, Chaix G, Laclau JP, Tomazello M Fo. Efeito da disponibilidade hídrica e da aplicação do potássio e sódio nas características anatômicas do lenho j0uvenil de Eucalyptus grandis. Revista Árvore 2015; 39(1): 406-416

Gattward JN, Almeida AA, Souza JO Jr, Gomes FP, Kronzucker HJ. Sodium-potassium synergism in Theobroma cacao: stimulation of photosynthesis, water-use efficiency and mineral nutrition. Physiologia Plantarum 2012; 146(3): 350-362. http://dx.doi.org/10.1111/j.13993054.2012.01621.x. PMid:22443491.

Gonçalves BF, Yamaji FM, Fernandez BO, Róz AL, Florian FS. Caracterização e comparação entre diferentes granulometrias de serragem de Eucalyptus grandis para confecção de briquetes. Revista do Instituto Florestal 2013; 25(2): 205-213.

Indústria Brasileira de Árvores - IBÁ. Relatório anual 2016. Brasília: IBA; 2015 [cited 2017 june 26]. 100 p. Available from: http://iba.org/images/shared/Biblioteca/ IBA_RelatorioAnual2016_.pdf

Mahapatra AK, Harris DL, Durham DL, Lucas S, Terrill $\mathrm{TH}$, Kouakou B. Effects of moisture change on the physical and thermal properties of Sericea lespedeza pellets. Asian Agricultural Engineering 2010; 1: 23-29.

Panshin AJ, Zeeuw C. Textbook of wood technology. 3rd ed. New York: Mcgraw-Hill; 1970.

Protásio TP, Alves ICN, Trugilho PF, Silva VO, Baliza AER. Compactação de biomassa vegetal visando a produção de biocombustíveis sólidos. Pesquisa Florestal Brasileira 2011; 31(68): 273-283. http://dx.doi.org/10.4336/2011. pfb.31.68.273.

Quirino WF, Pinha IVO, Moreira ACO, Souza F, Tomazello M Fo. Densitometria de raios x na análise da qualidade de briquetes de resíduos de madeira. Scientia Forestalis 2012; 40(96): 525-536.

Quirino WF, Vale AT, Andrade APA, Abreu VLS, Azevedo ACS. Poder calorífico da madeira e de resíduos lignocelulósicos. Biomassa \& Energia 2004; 1(2): 173-182.

Sette CR Jr, Deus JC Jr, Tomazello M Fo, Padua FA, Calil FN, Laclau JP. Alterações na qualidade da madeira de Eucalyptus grandis causadas pela adubação. Cerne 2014; 
20(2): 251-258. http://dx.doi.org/10.1590/01047760.20 1420021499.

Sette CR Jr, Laclau JP, Tomazello M Fo, Moreira RM, Bouillet JP, Ranger J et al. Source-driven remobilizations of nutrients within stem wood in Eucalyptus grandis plantations. Trees 2013; 27(4): 827-839. http://dx.doi. org/10.1007/s00468-012-0837-x.

Sette CR Jr, Tomazello M Fo, Dias CTS, Chagas MP, Laclau JP. Efeito da aplicação do potássio e sódio nas características do lenho de árvores de Eucalyptus grandis W. Hill aos 24 meses de idade. Revista Floresta 2009; 39(3): 535-546.

Sette CR Jr, Tomazello M Fo, Dias CTS, Laclau JP. Crescimento em diâmetro do tronco de árvores de Eucalyptus grandis W. Hill. Ex. Maiden e a relação com as variáveis climáticas e fertilização mineral. Revista Árvore 2010; 34(6): 979-990. http://dx.doi.org/10.1590/ S0100-67622010000600003.

Sette CR Jr, Tomazello M Fo, Lousada JLPC, Lopes D, Laclau JP. Relationship between climate variables, trunk growth rate and wood density of Eucalyptus grandis W. Will ex Maiden trees. Revista Árvore 2016; 40(2):337-346. http://dx.doi.org/10.1590/0100-67622016000200016.
Silva DA, Nakashima GT, Barros JL, Roz AL, Yamaji FM. Caracterização de biomassas para a briquetagem. Revista Floresta 2015; 45(4): 713-722. http://dx.doi.org/10.5380/ rf.v45i4.39700.

Subbarao GV, Chauhan YS, Johansen C. Patterns of osmotic adjustment in pigeonpea: its importance as a mechanism of drought resistance. European Journal of Agronomy 2000; 12(3-4): 239-249. http://dx.doi.org/10.1016/S11610301(00)00050-2.

Subbarao GV, Ito O, Berry WL, Wheeler LM. Sodium - A functional plant nutriente. Critical Reviews in Plant Sciences 2003; 22(5): 391-416. https://doi. org/10.1080/07352680390243495.

Temmerman M, Rabier F, Jensen PD, Hartmann H, Bohm T. Comparative study of durability test methods for pellets and briquettes. Biomass and Bioenergy 2006; 30(11): 964972. http://dx.doi.org/10.1016/j.biombioe.2006.06.008.

Washusen R, Baker T, Menz D, Morrow A. Effect of thinning and fertilizer on the cellulose crystallite width of Eucalyptus globulus. Wood Science and Technology 2005; 39(7): 569-578. http://dx.doi.org/10.1007/s00226005-0012-2. 